\title{
Influence of biofertilizer on essential oil, harvest index and productivity effort of black cumin (Nigella sativa L.)
}

\author{
Seyed Alireza Valadabadi ${ }^{\star}$ and Hossein Aliabadi Farahani \\ Faculty of Agriculture, Islamic Azad University, Shahr-e-Qods Branch, Tehran, Iran. \\ Accepted 9 May, 2013
}

\begin{abstract}
In order to investigate the effects of biofertilizer on essential oil harvest index and productivity effort of black cumin (Nigella sativa L), an experiment was conducted during the growing season of 2010 at Iran. The experimental design was factorial on the basis of randomized complete block design with three replications. Certain factors including four levels of animal manure $(0,10,20$ and 30 ton/ha, respectively) and two levels of azotobacter (non-application and application) were studied. The final statistical analysis indicated that in the $\mathbf{1 0}$ ton/ha animal manure and azotobacter application, essential oil, harvest index and productivity effort were significantly higher.
\end{abstract}

Key words: Biofertilizer, essential oil, Nigella sativa, harvest index.

\section{INTRODUCTION}

Nigella sativa is an annual flowering plant, native to southwest Asia. It grows to 20 to $30 \mathrm{~cm}$ in height, with finely divided, linear leaves. The flowers are delicate, and usually coloured pale blue and white, with 5 to 10 petals. The fruit is a large and inflated capsule composed of 3 to 7 united follicles, each containing numerous seeds. The seed is used as a spice. It is reported that intact black cumin seeds or their extracts have antidiabetic, antihistaminic, antihypertensive, anti-inflammatory, antimicrobial, antitumor and insect repellent effects (Riaz et al., 1996; Siddiqui and Sharma, 1996: Worthen et al., 1998). Black cumin oil has been used for many centuries in the Asian, European, Arabian and the Mediterranean countries. It is used for edible and medicinal purposes in Iran. The best method for extraction of black cumin oil is cold press; cold pressed oils are the highest quality oils available. The black cumin seed cake is a by-product obtained from the black cumin seeds with cold pressing and it is used in the production of bio-oil (Sen and Kar, 2012). Some studies show that the black cumin is able to tolerate moderate levels of water stress (Bannayan et al., 2008: Mozzafari et al., 2000). The potential of medicinal and aromatic plants to grow under limited water conditions make them suitable alternative crops in such agroecosystems (Koocheki and Nadjafi, 2003; Haj, 2011). Chemical fertilizers have several negative impacts on environment and sustainable agriculture. Therefore, biofertilizer is recommended in these conditions and growth prompting bacteria uses as a replacement for chemical fertilizers (Wu et al., 2005). Growth promoting bacteria are induced by increasing plant yield as clone in plant root (Gholami et al., 2009). Growth promoting bacteria include Azotobacter, Azospirillum and Pseudomonas (Turan et al., 2006). Tilak reported positive effects of double inoculation of maize and sorghum. Azotobacter is an anaerobic, free-living soil microbe which fixes nitrogen from the atmosphere. Beyond Azotobacter is used as a model. Organism has biotechnological applications. Examples are its use for alginate production and for nitrogen production in batch fermentations. Biofertilizers 
Table 1. The result of soil analysis.

\begin{tabular}{lcccccccccc}
\hline $\begin{array}{l}\text { Soil } \\
\text { texture }\end{array}$ & $\begin{array}{c}\text { Sand } \\
(\%)\end{array}$ & $\begin{array}{c}\text { Silt } \\
(\%)\end{array}$ & $\begin{array}{c}\text { Clay } \\
(\%)\end{array}$ & $\begin{array}{c}\mathbf{K} \\
(\mathbf{m g} / \mathbf{k g})\end{array}$ & $\begin{array}{c}\mathbf{P} \\
(\mathbf{m g} / \mathbf{k g})\end{array}$ & $\begin{array}{c}\mathbf{N} \\
(\mathbf{m g} / \mathbf{k g})\end{array}$ & $\begin{array}{c}\mathbf{N a} \\
(\mathbf{D s} / \mathbf{m})\end{array}$ & $\begin{array}{c}\text { EC } \\
(\mathbf{1}: 2.5)\end{array}$ & pH & $\begin{array}{c}\text { Depth of } \\
\text { sampling (cm) }\end{array}$ \\
\hline Clay loam & 35 & 30 & 35 & 142.2 & 5.2 & 38.7 & 0.05 & 0.18 & 7.9 & $0-30$ \\
\hline
\end{tabular}

are products containing living cells different types of microorganisms (Vessey, 2003; Chen, 2006) that have an ability to convert nutritionally important elements from unavailable to available form through biological processes (Vessey, 2003) and are known to help with expansion of the root system and better seed germination. Biofertilizers differ from chemical and organic fertilizers in that they do not directly supply any nutrients to crops and are cultures of special bacteria and fungi. Some microorganisms have positive effects on plant growth promotion, including the plant growth promoting rhizobacteria (PGPR) such as Azospirillum, Azotobacter, Pseudomonas fluorescens and several gram positive Bacillus spp. (Chen, 2006). Azotobacter and Azospirillum are freeliving $\mathrm{N}_{2}$ fixing-bacteria in the rhizospheric zone that have the ability to synthesize and secret some biologically active substances that enhance root growth. They also increase germination and vigour in young plants, leading to improved crop stands (Chen, 2006). It is well known that a considerable number of bacterial and fungal species possess a functional relationship and constitute a holistic system with plants. They are able to exert beneficial effects on plant growth (Vessey, 2003) and also enhance plant resistance to adverse environmental stresses, such as water and nutrient deficiency and heavy metal contamination (Wu et al., 2005).

Therefore, the objective of this study was to evaluate the biofertilizers influence on essential oil, harvest index) and productivity effort of black cumin (Nigella sativa L.

\section{MATERIALS AND METHODS}

This study was conducted on experimental field of Islamic Azad University, Shahr-e-Qods Branch at Iran (27³8' N,40²1'E;1417 m above sea level) during 2010, with clay loam soil (Table 1), mean annual temperature of $31^{\circ} \mathrm{C}$ and rainfall which is distributed with an annual mean of $215 \mathrm{~mm}$. The experimental unit was designed to achieve treatments in factorial on the basis of randomized complete block design with three replications. Certain factors including four levels of animal manure $(0,10,20$ and 30 ton/ha, respectively) and two levels of azotobacter (non-application and application) were studied. The soil consisted of $35 \%$ clay, $30 \%$ silt and $35 \%$ sand (Table 1). Each experimental plot was $3 \mathrm{~m}$ long and $2 \mathrm{~m}$ wide. Sowing was done manually with $0.5 \mathrm{~cm}$ depth and in rows with 25 $\mathrm{cm}$. Weeds were controlled manually. All necessary cultural practices and plant protection measures were followed uniformly for all the plots during the entire period of experimentation. At the end of the growth stage, we collected 10 plants from each plot randomly for determination of seed yield $(\mathrm{kg} / \mathrm{ha})$, capsule dry weight $(\mathrm{kg} / \mathrm{ha})$ and biological yield ( $\mathrm{kg} / \mathrm{ha}$ ) and $100 \mathrm{~g}$ seed were selected from each plot for determination of essential oil percentage by were determined using the following formulas:

Clevenger. Finally, harvest index (H.I) and productivity effort (P.E)
H.I = Seed yield / biological yield

P.E=Capsule dry weight / biological yield

Data were subjected to analysis of variance (ANOVA) using Statistical Analysis System (SAS) and followed by Duncan's multiple range tests. Terms were considered significant at $p<0.05$.

\section{RESULTS}

Final results of plants values showed that azotobacter significantly affected essential oil $(p \leq 0.01)$ harvest index and productivity effort $(p \leq 0.05)$ (Table 2$)$ which indicated that the highest essential oil $(21.8 \mathrm{~kg} / \mathrm{ha})$, harvest index $(22 \%)$ and productivity effort $(0.36)$ were obtained by azotobacter application (Table 3 ). Also, animal manure significantly affected essential oil $(p \leq 0.01)$, harvest index and productivity effort $(p \leq 0.05)$. The highest essential oil $(17.5 \mathrm{~kg} / \mathrm{ha})$ was obtained by application of $20 \mathrm{ton} / \mathrm{ha}$ animal manure but the highest productivity effort $(0.34)$ and harvest index (18\%) were obtained by application of 30 ton/ha animal manure (Table 3). Interaction of azotobacter and animal manure had significant effect on essential oil and harvest index but productivity effort did not respond to interaction of azotobacter and animal manure (Table 2) and highest essential oil (18.8 kg/ha), harvest index $(21.2 \%)$ were obtained under application of azotobacter and 10 ton/ha animal manure (Table 4).

\section{DISCUSSION}

In this study, increases in agronomic criteria were observed following inoculation with azotobacter. This may be due to better utilization of nutrients in the soil through inoculation of efficient microorganisms (Deka et al., 1992; Dixon et al., 2004). A positive effect of azotobacter on yield and yield components has been reported in the literature (Migahed et al., 2004). The results showed that application of azotobacter and animal manure increased essesntial oil, harvest index and productivity effort of black cumin. It is indicated that using biofertilizers caused increased harvest index due to effect on dry weight and allocating more photosynthetic matters to grain (Kumar et al., 2009; Mandal et al., 2007). It seems that using biofertilizers led to increasing productivity by affecting plant dry weight and allocating more minerals to stems, leaves and grain, so increasing biological and grain yield. Bashan and Levanony (1990) have shown that inoculation of plants with azospirillum can result in a significant change in various plant growth parameters. Another corn study showed that seed inoculation with azotobacter produced 
Table 2. Analysis of variance.

\begin{tabular}{lcccc}
\hline \multirow{2}{*}{ S.o.v } & df & \multicolumn{3}{c}{ Mean square } \\
\cline { 3 - 5 } & 2 & Essential oil & Harvest index & Productivity effort \\
\hline Replication & 2 & 0.005 & 12.721 & 0.00422 \\
Azotobacter (A) & 1 & $0.071^{* *}$ & $71.542^{\star}$ & $0.00912^{\star}$ \\
Animal manure (M) & 3 & $0.058^{* *}$ & $24.372^{*}$ & $0.0139^{\star}$ \\
A $\times$ M & 3 & $0.056^{* *}$ & $9.340^{\star}$ & 0.00673 \\
Error & 18 & 0.003 & 6.392 & 0.00376 \\
CV (\%) & & 2.77 & 8.08 & 11.05 \\
\hline
\end{tabular}

${ }^{*}$ and ${ }^{* *}$ :Significant at 5 and $1 \%$ levels, respectively.

Table 3. Means comparison.

\begin{tabular}{llccc}
\hline Treatment & & Essential oil (kg/ha) & Harvest index (\%) & Productivity effort \\
\hline \multirow{3}{*}{ Azotobacter (A) } & Non-application(A1) & $14.8^{\mathrm{b}}$ & $18.0^{\mathrm{b}}$ & $0.33^{\mathrm{b}}$ \\
& Application (A2) & $20.1^{\mathrm{a}}$ & $22.0^{\mathrm{a}}$ & $0.36^{\mathrm{a}}$ \\
& & & & \\
\multirow{5}{*}{ Animal manure (M) } & Non-application (M1) & $16.5^{\mathrm{b}}$ & $18.3^{\mathrm{a}}$ & $0.33^{\mathrm{b}}$ \\
& 10 ton/ha (M2) & $16.6^{\mathrm{b}}$ & $17.4^{\mathrm{ab}}$ & $0.32^{\mathrm{b}}$ \\
& 20 ton/ha (M3) & $17.5^{\mathrm{a}}$ & $16.6^{\mathrm{b}}$ & $0.33^{\mathrm{b}}$ \\
& 30 ton/ha (M4) & $16.2^{\mathrm{b}}$ & $18.0^{\mathrm{a}}$ & $0.34^{\mathrm{a}}$ \\
\hline
\end{tabular}

Means within the same column and rows and factors, followed by the same letter are not significantly difference $(P<0.05)$.

Table 4. Means comparison of interaction.

\begin{tabular}{lcc}
\hline Treatment & Essential oil (kg/ha) & Harvest index (\%) \\
\hline (A1).(M1) & $15.6^{\mathrm{c}}$ & $18.0^{\mathrm{c}}$ \\
(A1).(M2) & $15.7^{\mathrm{c}}$ & $17.8^{\mathrm{cd}}$ \\
(A1).(M3) & $16.1^{\mathrm{c}}$ & $19.0^{\mathrm{bc}}$ \\
(A1).(M4) & $15.7^{\mathrm{d}}$ & $17.7^{\mathrm{cd}}$ \\
$(\mathrm{A} 2) .(\mathrm{M} 1)$ & $18 \cdot 2^{\mathrm{b}}$ & $20.4^{\mathrm{a}}$ \\
$(\mathrm{A} 2) .(\mathrm{M} 2)$ & $18 \cdot 8^{\mathrm{a}}$ & $21.2^{\mathrm{a}}$ \\
(A1).(M3) & $16.3^{\mathrm{c}}$ & $19.1^{\mathrm{b}}$ \\
(A2).(M4) & $15 \cdot 6^{\mathrm{c}}$ & $18.2^{\mathrm{c}}$ \\
\hline
\end{tabular}

Means within the same column and row factors followed by the same letter are not significantly difference $(P<0.05)$.

significantly higher dry matter than from non-inoculation (Chela et al., 1993). Manjunatha et al. (2002) conducted a study on the effect of biofertilizer on growth, yield and essential oil content in Patchouli (Pogostemon cablin Pellet). The treatments included three levels each of nitrogen $(\mathrm{N})$ and phosphate $\left(\mathrm{P}_{2} \mathrm{O}_{5}\right)(50,75$ and $100 \%$ of recommended) with potash $\left(\mathrm{K}_{2} \mathrm{O}\right)$ at constant level of 50 $\mathrm{kg} / \mathrm{ha}$ along with different biofertilizers Azotobacter, Azospirillum, phosphorus solubilising bacteria (PSB) and vesicular arbuscular mycorrhizal fungi (VAM) in combination. The results revealed that the treatments differed significantly; among the treatments, $75 \% \mathrm{NP}+$ $100 \mathrm{~K}+$ Azotobacter + Azospirillum + VAM recorded significantly superior values for plant height $(80.14 \mathrm{~cm})$, number of branches (22.04) and essential oil yield (71.74 $\mathrm{l} / \mathrm{ha})$ as compared to the control $(47.5 \mathrm{l} / \mathrm{ha})$. On the whole, the treatment with $75 \% \mathrm{NP}+100 \mathrm{~K}+$ Azotobacter + Azospirillum + VAM emerged as one of the best treatments and effected the saving of fertilizers to the extent of $25 \%$. Also, an investigation was carried out under Madurai conditions of Tamil Nadu, India to study the influence of nitrogen, application of nitrogen and phosphorus on Azospirillum which gave the highest plant height, essential oil yield and harvest index. The changes were directly attributed to positive bacterial effects on mineral uptake by the plant. Enhancement in uptake of $\mathrm{NO}_{3}^{-}, \mathrm{NH}_{4}^{-}, \mathrm{PO}_{4}{ }^{2-}, \mathrm{K}^{+}$and $\mathrm{Fe}^{++}$by Azospirillum (Barton et al., 1986; Murty and Ladha, 1987) was proposed to cause an increase in dry matter and accumulation.

\section{Conclusion}

In general, it appears that, as expected, application of azotobacter improved yield and other plant criteria. Therefore, it appears that application of azotobacter and animal manure could be promising in production of black cumin by reduction of chemical fertilizer application. Our finding may give application advice to farmers for management and concern on fertilizer strategy and carefully estimate chemical fertilizer supply by biofertilizers application. 


\section{REFERENCES}

Barton IL, Johnson GV, Arbock MS (1997).The effect of azosprillum brasilnse on iron absorption and translocation by sorghum. J. Plant Nutr. 9:557- 565

Bashan Y, Levanony H (1990). Current status ofzospirillum inoculation technology:Azospirillum as a challeng for agriculture. Can J. Microbial. 36:591-608.

Chen $J$ (2006). The combined use of chemical and organic fertilizers and/or biofetilizer for crop growth and soil fertility.International Workshop on Sustained Management of the Soil-Rhizosphere System for Efficient Crop Production and Fertilizer Use.16- 20 October, Thailand.

Deka BC, Bora GC, Shaequel provide initial of author (1992). Effect of Azopirillum growth and yield of chilli (Capsicum annum L) cultivr Pusa Jawala.Haryana. J. Hot. Sci. 38:41-46.

Dixon R, Kahn D (2004). Jenetic iegulation of biological nitrogen fixation. Nat. Rev. Microbial. 2(8):621-631.

Gholami A, Shahsavani S, Nezarat S (2009).The effect of PlantGrowth Rhizobacteria(PGPR) on germination,seedling growth and yield of maize.World Acad. Sci. Eng.Technol. 49:19-24.

Koocheki A, Nadjafi F(2003) .The status of medicinal and aromatic plants in Iran and strategies for sustainable utilization. In: Abstract Book of The $3^{\text {rd }}$ World Congress on Medicinal Aromatic Plants for HumanWelfare, Februrary3-7,2003,Chaing Mai, Thailland, p.283.

Kumar TS, Swaminathan V, Kumar S (2009). Influence of nitrogen, phosphorus and biofertilizers on growth, yield and essential oil constituents in ratoon crop of davana (Artemisia pallens Wall). Electronic J. Environ. Agric. Food Chem. 8(2):86-95.

Mandal A, Patra AK, Singh D, Swarup A, Ebhin Mast R (2007). Effect of long-term application of manure and fertilizer on biological and biochemical activities in soil during crop development stages. Biores. Technol. 98:3585-3592.
Manjunatha $R$, Farooqi AA, Vasundhara M, Srinivasappa KN (2002). Effect of biofertilizer on growth, yield and essential oil content in patchouli (Pogostemon cablin Pellet.). Indian Perfumer. 46 (2):97104.

Migahed HA, Ahmed AE, Abd El-Ghany BF(2004). Effect of different bacterial strains as biofertilizer agents on growth, production and oil of Apium graveolense under Calcareous soil. J. Agric. Sci. 12:511525.

Murty MG, ladha JK (1987). Differential colonization of azospirillum lipoferum on roots of two varieties of rice (oryza sativa). Biol Fertil. Soil 4:3-7.

Sen N, Kar Y (2012). Pyrolysis of black cumin seed cake in a fixed-bed reactor. J. Biomass Bioenergy 35:4297-4304.

Siddiqui AA, Sharma PKR (1996).Clinical importance of Nigella sativa L. A review. Hamdard Med. 39(2):23-26.

Tilak KVBRM (1992). Azospirillum brasilense and Azotobacter chrooccocum inoculum effect of maize and sorghum. Soil Bio. Biochem.14;417-418.

Turan M, Ataoglu N, Sahin A (2006). Evaluation of the capacity of phosphate solubilizing bacteria and fungi on different forms of phosphorus in liquid culture. Sus. Agric. 28:99-108.

Vessey JK (2003). Plant growth promoting rhizobacteria as biofertilizers. Plant Soil 255:571-586.

Worthen DR, Ghoshen OA, Crooks PA (1998). The in vitro anti-tumor activity of some crude and purified components of black seed, Nigella sativa L. Anticancer Res. 18:1527-1532.

Wu SC, Caob ZH, Lib ZG, Cheung KC, Wong MH (2005). Effects of biofertilizer containing $\mathrm{N}$-fixer, $\mathrm{P}$ and $\mathrm{K}$ solubilizers and AM fungi on maize growth : a greenhouse trial. Geoderma. 125:155-166. 